\title{
A residualis kockázat útvesztői: a maradék lipid és gyulladásos kockázat csökkentése az atherosclerosis prevenciójában
}

\author{
Márk László dr. ${ }^{1}$ - Harangi Mariann dr. ${ }^{2}$ - Paragh György dr. ${ }^{2}$ \\ ${ }^{1}$ Békés Megyei Központi Kórház Pándy Kálmán Tagkórháza, II. Belgyógyászat-Kardiológia, Gyula \\ ${ }^{2}$ Debreceni Egyetem, Általános Orvostudományi Kar, Belgyógyászati Intézet, Anyagcsere-betegségek Tanszék, \\ Debrecen
}

\begin{abstract}
A cardiovascularis betegségek kockázatának csökkentése meghatározó jelentőségú napjaink orvoslásában, mivel világszerte a legtöbb halált okozzák. Sokfajta kezelésről sikerült egyértelműen igazolni, hogy kedvezően hat a cardiovascularis események gyakoriságára, valamint az azok kialakulásához vezető atherosclerosis fejlődésére. Ezen kezelések szisztematikus, irányelvek szerinti alkalmazásával sikerült csökkenteni az éresemények számát és a halálozást, de a betegségcsoport mortalitási és morbiditási vezető pozíciója megmaradt. Emiatt az orvostudományi kutatás folyamatosan új utakat keres a mai tudásunk alapján felállított irányelvek optimális megtartása mellett megmaradó kockázat további csökkentésére. Ez a residualis rizikó sokrétú lehet. A szerzők a jelen munkájukban összefoglalják, hogy az irányelvek szerinti kezelés után milyen új lehetőségek vannak a residualislipid- és gyulladásos kockázat csökkentésére. Több lipidológiai vizsgálat is igazolta, hogy az 1,8 mmol/1 alá csökkentett LDL-koleszterin-szinttel további nyereség érhető el az éresemények előfordulásában. A maradéklipidológiai kockázatot csökkentené a magas triglicerid- és az alacsony HDL-koleszterin-szint kezelése, valamint a magas lipoprotein(a) csökkentése. A lipidszintek kezelésén túl a C-reaktívprotein-szint-csökkentés által igazolt antiinflammatorikus hatásukon keresztül is hatnak a statinok és a velük kombinálható ezetimib. A kizárólag csak a gyulladást befolyásoló hatását gátló canakinumab alkalmazásával történt nagy léptékü klinikai vizsgálat (melyben 3 havonta adott sc. injekcióval szignifikánsan, 15\%-kal csökkent a nem halálos infarktus és stroke, valamint a cardiovascularis halál előfordulása) új távlatokat nyit az atherosclerosis gyulladáscsökkentő kezelésében.
\end{abstract}

Orv Hetil. 2018; 159(4): 124-130.

Kulcsszavak: prevenció, koleszterin, statinok, ezetimib, C-reaktív protein

\section{The labyrinth of residual risk: reduction of the remaining lipid and inflammation risk in the prevention of atherosclerosis}

Since cardiovascular diseases are the main cause of mortality worldwide, the reduction of their risk is a crucial point of present-day medicine. It has been proven unequivocally that the administration of various treatments has a favorable effect on the frequency of cardiovascular events and on the atherosclerosis leading to them. Although systematic and guideline-driven administration of these drugs has led to a decrease in the incidence and mortality of vascular events, the leading position of this group of diseases in mortality and morbidity has not changed. That is why medicine, besides keeping up actual guidelines optimally, is always searching for new modalities to further decrease residual risk. This residual risk can be diverse. The present paper summarizes the possibilities of reducing residual lipid and residual inflammatory risk after treatment according to the guidelines. It has been proven that lowering LDLcholesterol below $1.8 \mathrm{mmol} / \mathrm{l}$ has a further advantage on the occurrence of vascular events. Treating the elevated lipoprotein(a), triglyceride and low HDL-cholesterol levels should decrease the residual lipid risk. Statins and statinezetimibe combination, besides lipid modulation, have an anti-inflammatory effect proved by C-reactive protein level reduction. Canakinumab has solely inflammation reducing effect through the inhibition of interleukin- $1 \beta$. It was administered subcutaneously once in 3 months in a large-scale clinical study and it has shown a $15 \%$ reduction in non-fatal myocardial infarction, non-fatal stroke and cardiovascular death, which opens new horizons in the anti-inflammatory treatment of atherosclerosis. 
Keywords: cholesterol, prevention, statins, ezetimibe, C-reactive protein

Márk L, Harangi M, Paragh Gy. [The labyrinth of residual risk: reduction of the remaining lipid and inflammation risk in the prevention of atherosclerosis]. Orv Hetil. 2018; 159(4): 124-130.

(Beérkezett: 2017. október 9.; elfogadva: 2017. október 24.)

\begin{abstract}
Rövidítések
ApoB = apolipoprotein-B; CANTOS = Canakinumab Anti-Inflammatory Thrombosis Outcomes Study; CETP = koleszterinészter-transzfer protein; CRP $=$ C-reaktív protein; CTTC $=$ Cholesterol Treatment Trialists' Collaboration; eGFR = becsült glomerularis filtrációs ráta; FOURIER-vizsgálat = Further Cardiovascular Outcomes Research With PCSK9 Inhibition in Subjects With Elevated Risk; HDL = (high-density lipoprotein) magas sürüségû lipoprotein; HDL-C = (highdensity lipoprotein cholesterol) magas sürúségú lipoproteinkoleszterin; hsCRP = (high-sensitivity $\mathrm{C}$-reactive protein $)$ nagy érzékenységü C-reaktív protein; IMPROVE-IT-vizsgálat = IMProved Reduction of Outcomes: Vytorin Efficacy International Trial; ISZB = ischaemiás szívbetegség; JUPITER-vizsgálat = Justification for the Use of statins in Primary prevention: an Intervention Trial Evaluating Rosuvastatin; LDL $=($ low-density lipoprotein $)$ alacsony sűrűségű lipoprotein; LDL-C = (lowdensity lipoprotein cholesterol) alacsony sűrüségű lipoproteinkoleszterin; Lp(a) = lipoprotein(a); Lp-PLA2 = (lipoproteinassociated phospholipase A2) lipoproteinasszociált foszfolipázA2; PCSK9 = proproteinkonvertáz szubtilizin/kexin-9; REVEAL-vizsgálat = Randomized Evaluation of the Effects of Anacetrapib through Lipid Modification; SOLID-TIMI 52 vizsgálat $=$ Stabilization Of pLaques usIng Darapladib-Thrombolysis in Myocardial Infarction; TG = triglicerid
\end{abstract}

A legtöbb haláleset az atherosclerosis, valamint az annak következményeként kialakuló plakkok rupturájának következménye. Megfigyelések azt igazolják, hogy a rupturához vezetó instabilitás nem mindig a legjelentősebb lumenszúkületet okozó plakkokon alakul ki. Még nem sikerült annak az útnak a teljes megismerése és azoknak a tényezőknek a maradéktalan meghatározása, amelyek a coronariák stabil plakkjainak vulnerábilis plakká alakulását okozzák [1].

A plakk képződése lassú, évtizedekig tartó, korábban degeneratívnak, ma inflammatorikusnak tartott dinamikus folyamat, mely azzal kezdődik, hogy a low-density lipoprotein (LDL)-részecskék közvetítésével koleszterin rakódik le az érfalban. Az oxidált LDL a makrofágokba jutásával azokat habos sejtekké alakítja, melyek a plakkba kerülnek. A folyamatot az antiatherogen hatású highdensity lipoprotein (HDL) a reverz koleszterintranszport útján lassítja, aminek az ereje a HDL funkcionalitásának is következménye. A koleszterin plakkban történő lerakódása annak nekrotikus magjában (core) koleszterinkristályok képződéséhez vezet, melyek a plakk mechanikus károsításával annak rupturáját is kiváltó tényezők lehetnek. A plakkban képződő koleszterinkristályok a kezdeti stádiumban triggerei a szisztémás gyulladásnak [2]. (A koleszterin és a gyulladás mellett az instabil plakk kialakulásában harmadik meghatározó tényezőként nagy szerepe van a jelen közlésben nem részletezett thromboticus folyamatoknak.)

$\mathrm{Az}$ atherosclerosis kezelésében a legjobb terápiás lehetőség a primer prevenció lenne. Yusuf és mtsai felmérése igazolta, hogy a heveny éresemények több mint 90\%ának kialakulását környezeti okok, rizikófaktorok magyarázhatják [3], ami azt támasztja alá, hogy a plakkok kialakulásának és növekedésének nagyobb része megelőzhető a kockázati tényezők eliminálásával. A rizikófaktorok jelentőségét nem kisebbíti az, hogy ma a gyulladást tartjuk az atherogenesis alapvető mechanizmusának. A rizikófaktorokat lényegében a gyulladás köti az érfalhoz, azaz a rizikófaktorok endotheldiszfunkciót okoznak, gyulladásos folyamatot indukálnak az érfalban, és így indítják el vagy rontják tovább az atherosclerosist. A plakk lipidtartalmának megnövekedése a sok makrofág, a kevés simaizomsejt és a vékony kötőszövetes fedőréteg mellett az instabilitás egyik fö tényezője. Az okkluzív plakk okozta anginás tünetek megoldására a revascularisatiós beavatkozások alkalmasak, de meg kellene akadályoznunk azt, hogy egyáltalán idáig jusson a folyamat.

A kardiológiai irányelvekben állásfoglalás található arról, hogy a bizonyítékokon alapuló orvoslás jelenlegi állása szerint miként történjen az atherosclerosis megelőzése és progressziójának gátlása. Nem állítható viszont, hogy ha mindent elöírás szerint végeznénk, teljes mértékben meg tudnánk előzni a vascularis események kialakulását, bizonyos mértékủ kockázat ugyanis mindig marad. Ez lehet olyan rizikófaktorok megléte miatt, amelyeket nem tudunk befolyásolni (életkor, nem), vagy esetleg nem is ismerünk még, de lehet azért is, mert a jelenlegi kezelési elveket az újabb kutatások eredményei szerint tovább kellene finomítani. Az irányelvek szerinti optimális kezelés után megmaradó kockázat, a residualis kockázat megfelelő kezelése az atherosclerosis kezelésében is nagy jelentőséggel bírna (1. ábra) [4], ennek újabb lehetőségeire hívjuk fel a figyelmet a közelmúlt nagy klinikai vizsgálati eredményeinek ismertetésével, fóleg a residualislipid- és gyulladásos rizikó oldaláról.

$\mathrm{Az}$ atherosclerosis kialakulásának koleszterin- és gyulladásos hipotézise a folyamat egymást kiegészítő megközelítései. A kezelés lehet bármelyik oldal önmagában vagy a kettő együtt is. Az együttes kezelésre jó példa a statinok adása, ami a koleszterinszint csökkentése mellett 




1. ábra

a gyulladásos marker C-reaktív protein (CRP) szintjét is mérsékelni tudja [5].

Ma a szokványos nagy tényezők (dohányzás, magas vérnyomás és koleszterinszint) mellett már a gyulladásos markerek emelkedett szintjét is rizikófaktornak tartjuk. Szív- és érrendszeri betegség fennállása esetén vagy annak prevenciójára terápiás célnak tekinthetjük a gyulladásos folyamatok visszaszorítását. Ismert érbetegség fennállásakor az irányelvek szerinti kezelés elindításával többek között nagy dózisú statint kapnak a betegek. Az individuális különbségekből adódóan erre nem azonos

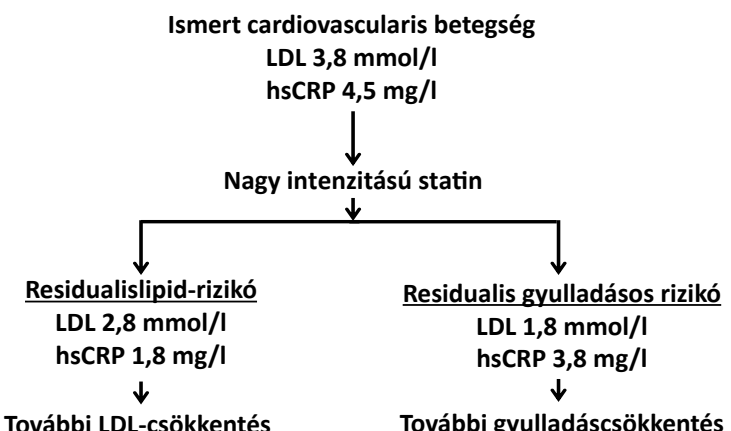

IMPROVE-IT: Ezetimib 6\% RRR FOURIER/SPIRE: PCSK9-gátlás 15\% RRR

2. ábra

A residualislipid-kockázat és a residualis gyulladásos kockázat: az atherosclerosis megelőzésében mindkettőre hatva jelentősebb a csökkenés az éresemények számában módon reagálnak, az LDL-koleszterin (LDL-C) és a szisztémás gyulladás markere, a CRP eltérő mértékben csökkenhet, azaz az elő́rás szerinti optimális kezelés után is maradhat kockázat, residualislipid- (koleszterin-, triglicerid [TG]- vagy HDL-C-) kockázat vagy residualis gyulladásos kockázat (2. ábra) [6]. A gondolatmenet folytatásaként beszélhetnénk residualis thromboticus kockázatról is, de ez nem tárgya a jelen munkánknak.

\section{A residualislipid-kockázat}

Az optimális kezelés utáni residualislipid-kockázat csökkentésének lehetőségei a koleszterin vagy LDL-C további csökkentése, valamint a magas TG csökkentése és az alacsony HDL-C emelése.

\section{$A z L D L-C$ további csökkentése}

A jelenlegi európai és magyar irányelvekben az LDL-Ccélértékek elérése elsődleges fontosságú, ami igen nagy kockázat esetén 1,8 mmol/l. Jó lenne, ha ez a betegek nagy részében meg is valósulna, de a napi gyakorlat adatai szerint még bőven van javítanivalónk. Ugyanakkor több vizsgálat igazolta, hogy $1,8 \mathrm{mmol} / 1$ alatti LDL-C esetén további nyereség érhető el. A nagy klinikai vizsgálatok közül a JUPITER-ben (Justification for the Use of statins in Primary prevention: an Intervention Trial Evalu- 


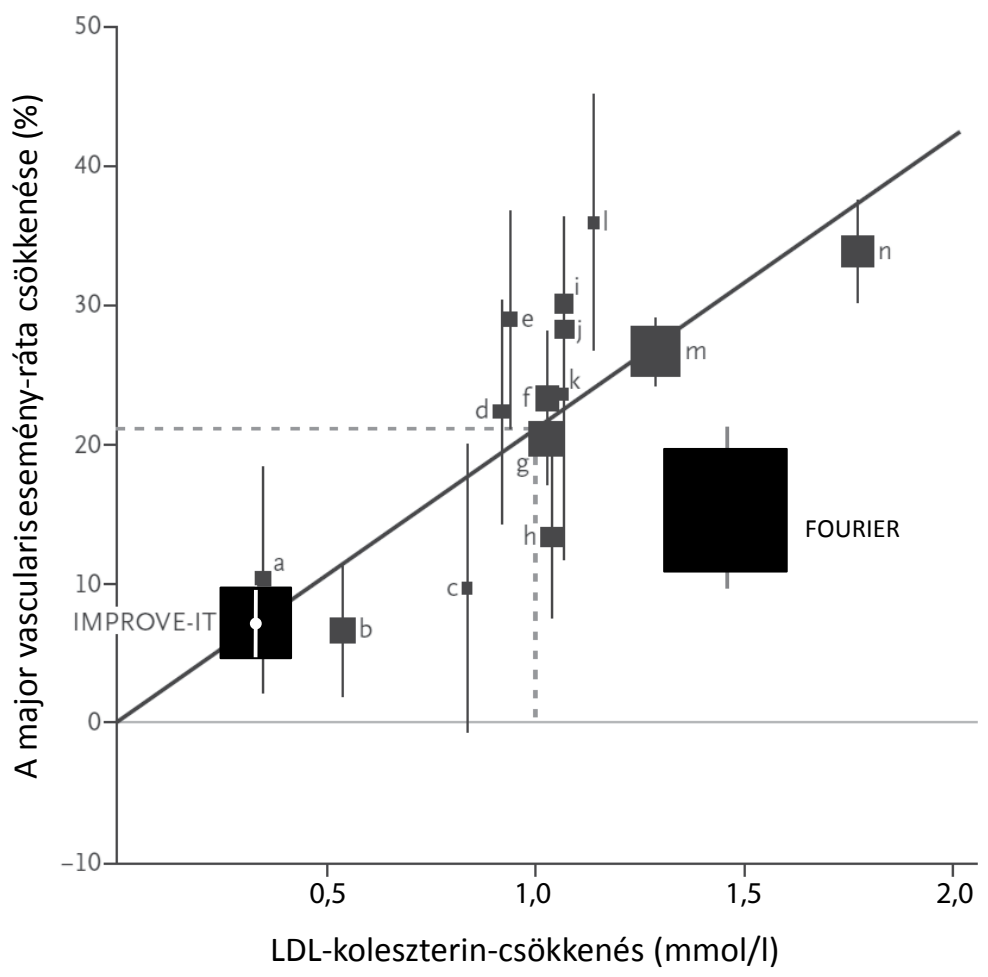

GISSI Prevenzione

b ALLHAT-LLT

c ALERT

d LIPS

e AFCAPS/TexCAPS

f CARE

g LIPID

h PROSPER

i ASCOT-LLA

j WOSCOPS

k Post CABG

I CARDS

m HPS

n $4 S$

3. ábra

| Az LDL-C-csökkenés és a major vascularisesemény-gyakoriság lineáris összefüggése

ating Rosuvastatin) [7] az aktív ágon 1,4, az IMPROVEIT-ben (IMProved Reduction of Outcomes: Vytorin Efficacy International Trial) [8, 9] 1,38, a FOURIERben (Further Cardiovascular Outcomes Research With PCSK9 Inhibition in Subjects With Elevated Risk) [10] $0,78 \mathrm{mmol} / 1$ volt az elért érték. Minél alacsonyabb tartományban van a kiindulási LDL-C, annál kisebb a várható kedvező hatás mértéke, de ezzel együtt törekedni kell a kockázat további csökkentésére. Az IMPROVE-IT LDL-C-értékeihez tartozó eseményszámok teljes mértékben megfelelnek a CTTC (Cholesterol Treatment Trialists' Collaboration) regressziós egyenese alapján vártaknak, a 3. ábra az eredeti egyenes vizsgálatai mellett az IMPROVE-IT és a FOURIER helyét is ábrázolja [11, $12]$.

\section{A magas TG és az alacsony $H D L-C$ kezelése}

A lipidológiában a residualis rizikó kifejezés először a koleszterin- vagy LDL-C-csökkentésen túli lipidprofil-javítás, a TG-csökkentés és a HDL-C-emelés vonatkozásában jelent meg. Erre lényegében a fibrátok lennének a megfelelő szerek, és figyelembe véve, hogy az elsőként választandó kezelésnek mindig a statinnak kell lennie, a fenofibrátot kell választani, mert az jól kombinálható bármelyik statinnal. Sajnálatos, hogy nem készült olyan nagy klinikai tanulmány, amely statinnal történt LDLC-célérték-elérés után magas TG- vagy alacsony HDLC-szintű betegeken vizsgálta volna a fibrátok hatását. Alcsoportelemzések és szakértői konszenzus alapján kijelenthető, hogy a residualislipid-kockázat csökkentésére
- ha a statinterápiával elértük az LDL-C-célértéket, és magas (2,3 mmol/l feletti) TG-szint és/vagy alacsony HDL-C maradt - fenofibrát adható az ajánlások szerint, aminek evidenciaszintje IIb/B vagy IIb/C [13-15].

\section{A HDL-C emelése}

A HDL kedvező hatásai a reverz koleszterintranszport fokozása, valamint az antioxidáns, az endothelvédő, a thrombocytagátló, a véralvadási kaszkádot gátló hatás, melyek alapján antiatheroscleroticus, atherosclerosisregressziós hatás várható, amit az ApoAl-Milano infúziós alkalmazása kis betegszámon igazolt.

Dohányzóknál a dohányzás elhagyása is emelheti a HDL-C-szintet, emellett gyulladáscsökkentő hatása is van.

A koleszterinészter-transzfer protein (CETP) a koleszterinészterek és a triglicerid cseréjét katalizálja a lipoproteineken. A CETP-gátlásnak jelentős HDL-koleszterinszint-emeló hatása van, ugyanakkor az ebbe a csoportba tartozó torcetrapib, dalcetrapib és evacetrapib kedvező hatását klinikai vizsgálatok nem tudták egyértelműen igazolni. A dalcetrapib jó hatásúnak tünt egy meghatározott genetikai polimorfizmusban, ezt igazolandó klinikai vizsgálat folyamatban van. Az anacetrapib a jelentős HDL-emelő hatás mellett a korábban említett szerekkel szemben kevésbé emeli az aldoszteronszintet és a vérnyomást. A Randomized Evaluation of the Effects of Anacetrapib through Lipid Modification (REVEAL-) vizsgálat 30 449, atheroscleroticus érbetegségben szenvedő, atorvastatinkezelésben részesülő betegen vizsgálta 
4,1 éves átlagos követési idővel 100 mg anacetrapib vagy placebo hatását. Induláskor az LDL-C-szint 1,58 $\mathrm{mmol} / 1$ volt. A kezelés hatására a non-HDL-C 18\%-kal, a direkt módszerrel meghatározott LDL-C 41\%-kal csökkent, a HDL-C 104\%-kal nőtt. A primer végpont (coronariaeredetű halál, szívinfarktus, coronariarevascularisatio) szignifikánsan, 9\%-kal csökkent (RR 0,91, 95\% CI $0,85-0,97, \mathrm{p}=0,004)$. Az anacetrapibcsoportban szignifikánsan, 0,7 Hgmm-rel magasabb vérnyomás volt (hasonlóan a dalcetrapib- és az evacetrapibvizsgálatokhoz és jelentősen kevesebb, mint a torcetrapib adásától megfigyelt $5 \mathrm{Hgmm}$ ), és szignifikánsan, 0,84\%-kal több betegnek csökkent 60 alá az eGFR-értéke. Ugyanakkor 0,6\%-kal, szignifikánsan kevesebb új keletú diabetes alakult ki. Nehéz megítélni, hogy a primer végpont csökkenésében mennyi tulajdonítható a HDL-C emelésének és mennyi az LDL-C, valamint a non-HDL-C csökkentésének. A 9\%-os csökkenés nem látszik soknak, de ebben az LDL-C-tartományban (az indulási LDL-C 1,58 mmol/1, igen alacsony volt) elfogadható, és úgy tünik, hogy a magasabb indulási LDL-C-szintü betegekben jelentősen kedvezőbb volt a hatás [16]. Felmerülhet azonban az is, hogy a 9\%-os kockázatcsökkenés az LDL-partikulumok számának csökkenésével (apolipoprotein-B [ApoB]csökkenés 18\%), nem pedig a partikulumok koleszterintartalmával függ össze (a direkt LDL-C-csökkenés 41\%). A korábban vizsgált gyógyszerek (statinok, ezetimib, PCSK9-inhibitorok) esetében az LDL-C- és az ApoBcsökkenés mértéke erôsen korrelált, így a gyógyszertől várható cardiovascularisrizikó-csökkenés mértéke jól becsülhető az LDL-C-csökkentő hatásból. A CETP-inhibitorok esetében nem függ össze ilyen jelentős mértékben a két paraméter, ami magyarázhatja a korábbi vizsgálatokban született ellentmondásos eredményeket is [17].

\section{A magas lipoprotein(a)-szint csökkentése}

A lipoprotein(a) [Lp(a)] vizsgálati és genetikai adatok szerint önálló rizikófaktora az atherosclerosisnak és az aortastenosisnak. Tulajdonságaiban az LDL-hez, szerkezetében a plasminogenhez hasonló. A szintje genetikailag meghatározott. Rutinszerú ellenőrzése nem ajánlott, az európai lipidajánlás szerint a meghatározása familiaris hypercholesterinaemia, korai ischaemiás szívbetegség (ISZB), a családban korai ISZB vagy ismert magas Lp(a)szint, optimális lipidkezelés mellett recidiváló koszorúéresemény esetén jön szóba. A magas Lp(a)-szintre a statinoknak nincs hatásuk, és az életmódnak sem jelentős a szerepe. A forgalomban nem lévő hosszú hatású nikotinsav (niacin) 30-40\%-os csökkenést tudott elérni, és hasonló mértékben hatottak a PCSK9-gátlók, ugyanakkor akár 50-80\%-os redukciót eredményezhet a szelektív LDL-aferézis-kezelés. A PCSK9-gátlók ily módon az $\mathrm{Lp}(\mathrm{a})$-ra hatva is csökkenteni tudják a residualislipidkockázatot $[13,18]$.

Az Lp(a) jelentősége eltörpül az LDL-C-é mellett, ami a leginkább abból adódik, hogy a szokásos terápiás ajánlásokkal korábban nem tudtuk befolyásolni, és nincs is olyan klinikai vizsgálat, amely direkt módon igazolná, hogy csökkentésével a cardiovascularis események kedvezően befolyásolhatók. Az irányelveknek megfelelően elsődlegesen az LDL-C csökkentendő, és csak ha célértéken lévő betegnél van recidív esemény, akkor kell meghatározni és megpróbálni csökkenteni az $\operatorname{Lp}(\mathrm{a})-\mathrm{t}$ is.

\section{A residualis gyulladásos kockázat}

Történtek próbálkozások annak igazolására, hogy a gyulladás mint residualis kockázati tényező kezelésével kedvezően lehet befolyásolni a cardiovascularis események gyakoriságát. Lényegében hasonló történt a JUPITER kapcsán is, ahol bevételi kritérium volt a gyulladás biomarkerének tekinthető magas CRP-szint. Sikertelen volt a foszfolipázgátló darapladib adása. Ennek a plakkstabilizáló hatású, a plakkban található érspecifikus gyulladásos enzimnek, az Lp-PLA2-nek (lipoproteinasszociált foszfolipáz-A2) a szintjét szelektíven gátló szernek a kedvező hatását nem tudta igazolni a SOLID TIMI 52 vizsgálat [19].

\section{$A z L D L-C$ és a CRP együttes csökkenése statin vagy statin és ezetimib adásával}

A JUPITER-vizsgálat tervezése azzal a céllal történt, hogy primer prevenciós, az akkori irányelvek szerint statin adására nem szoruló, de magas hsCRP-szintû ( $\geq 2$ $\mathrm{mg} / \mathrm{l})$ betegeken tesztelje placebóval szemben adott 20 mg rouvastatin hosszú távú hatását. A 17802 betegben a rosuvastatin 1 év után az átlag $2,8 \mathrm{mmol} / \mathrm{l}$-es kiindulási LDL-C-t 50\%-kal (1,4 mmol/l-re), a 4,2 mg/l-es hsCRP-szintet 37\%-kal csökkentette. Az aktívan kezeltekben $44 \%$-kal csökkent a primer végpont (myocardialis infarktus, stroke, revascularisatio, instabil angina miatti hospitalizáció és cardiovascularis halálozás összetettje), 20\%-kal pedig a bármely okból bekövetkezett halál. Az adatok alapján nem lehetett szétválasztani, hogy mennyi hatás származott a jelentős LDL-C-csökkenéstől és mennyi a CRP-csökkenéstől, de a legkedvezőbb hatást akkor tapasztalták, amikor az LDL-C-szint 1,8 mmol/1 alatt és a hsCRP $2 \mathrm{mg} / \mathrm{l}$ (vagy még inkább $1 \mathrm{mg} / \mathrm{l}$ ) alatt volt. Az eredmények ismeretében felmerült, hogy a kezelésben mindkét paramétert figyelembe kell venni ( „dual target”) [5, 20].

Az akutcoronaria-szindrómás betegeken történt IMPROVE-IT utólagos elemzésével tanulmányozták, hogy jobb klinikaiesemény-gyakorisággal párosul-e, ha az LDL-C-célérték elérése mellett a hsCRP is alacsony. Azt találták, hogy abban a betegcsoportban, ahol 1,8 mmol/1 alatt volt az LDL-C-szint és $2 \mathrm{mg} / \mathrm{l}$ alatt a hsCRP-szint, 27\%-kal kevesebb végpontesemény (cardiovascularis halál, szívinfarktus, stroke) fordult elő, mint ahol egyik célértéket sem érték el. A kettős célt (LDL-C és CRP) szignifikánsan többen érték el a simvastatin + ezetimib 
csoportban, mint a statin-monoterápiában ( $50 \%$ vs. $29 \%$, $\mathrm{p}<0,001$ ) [21]. Ezek az eredmények is azt mutatják, hogy statin vagy statin + ezetimib adásával az elért LDLC-csökkentő hatás mellett csökken a hsCRP is. A lipidcsökkentés és a gyulladáscsökkentés egyaránt befolyásolja a klinikai események gyakoriságát, de a két hatást itt nem lehet különválasztani.

\section{A canakinumab batása}

A gyulladásos rizikó csökkentése mint terápiás cél lehetőségének alátámasztására nagyon figyelemre méltó eredményt hozott viszont a humán monoklonális ellenanyag canakinumab adása, mely az atherothromboticus folyamat kialakulásában kulcsszerepet játszó proinflammatorikus citokin, az interleukin- $1 \beta$ hatását gátolja. Az érfalba kerülő koleszterinkristályok, gyulladásos sejtek, például neutrophil granulocyták, a hypoxia és a módosult áramlási viszonyok az interlekulin-1 $\beta$ (IL-1 $\beta$ ) aktivációjához vezetnek a kaszpáz-1-aktivitás következtében, valamint az inflammaszómákban képződő NLRP3 aktivációja által. A felszabaduló IL-1 $\beta$ hatására megnő a keringő interleukin-6 (IL-6) szintje, ami a májban további akutfázis-fehérjék: plazminogénaktivátorinhibitor-1 (PAI-1), fibrinogén és C-reaktív protein (CRP) felszabadulásához vezet. A kialakult szisztémás alacsony fokú gyulladás számos ponton károsítja az érfali múködést, és az érelmeszesedés progresszióját okozza. A folyamat korai szereplői: az NLRP3, az IL-1 $\beta$ és az IL-6 új terápiás célpontot jelentenek az érelmeszesedés kialakulásának megelőzésében. A canakinumab, az anakinra és a kolchicin IL-1 $\beta$ gátló hatással bír, a tocilizumab IL-6-receptor-gátló, míg a methotrexat gátolja az IL-6-szintézist (4. ábra) [22].
A Canakinumab Anti-Inflammatory Thrombosis Outcomes Study (CANTOS) egy 2017 augusztusában bemutatott, 39 ország 10061 betegének bevételével végzett nagy klinikai vizsgálat volt az atherothrombosis gyulladásos hipotézisének igazolására. A szívinfarktuson átesett stabil ISZB-s, tartósan $2 \mathrm{mg} / 1$ feletti hsCRPszintü betegek kettős vakrandomizáció után a szokásos terápia mellett 3 havonta sc. injekcióban kaptak $50 \mathrm{mg}$ (2170 fó), $150 \mathrm{mg}$ (2284 fó) vagy $300 \mathrm{mg}$ (2263 fó) canakinumabot, 3344 fó pedig placebót. A 61 éves átlagéletkorú csoportokban a 48 hónap követési idő alatt a lipidértékek nem változtak, az LDL-C 2,0 mmol/1 körül volt. A hsCRP szintje 39\%-kal esett, míg a primer végpont (nem halálos infarktus és stroke, valamint a cardiovascularis halál) 15\%-kal csökkent (HR 0,85, 95\% CI 0,76-0,96, p = 0,007). Azokban a betegekben, akiknek a hsCRP-szintje jobban csökkent, szignifikánsan erősebb volt a primervégpont-események csökkenése is. Nem változott az összhalálozás, több volt a fatális infekció a canakinumabcsoportban, és ritkább az arthritis, az osteoarthritis és a köszvény. Említésre méltó eredmény, hogy kevesebb volt a rák miatti halálozás, különös tekintettel a tüdőrákra (a gyulladás hatással lehet a tumorok kialakulására, növekedésére, invazivitására és a metasztázisok progressziójára), ami miatt onkológiai klinikai vizsgálat is indul [23]. A vizsgálat történelmi jelentősége, hogy a cardiovascularis események gyakoriságát a lipidszintek befolyásolása nélkül, a gyulladásra hatva (annak markereként a hsCRP-szint redukciójával) tudta csökkenteni.

A terápiás irányelvek maradéktalan betartása mellett is számítani lehet arra, hogy a cardiovascularis események egy része bekövetkezik $[14,24]$. Az optimális kezelés ellenére megmaradó kockázat további csökkentése a kardiológia, a prevenció további fejlődési iránya lehet.

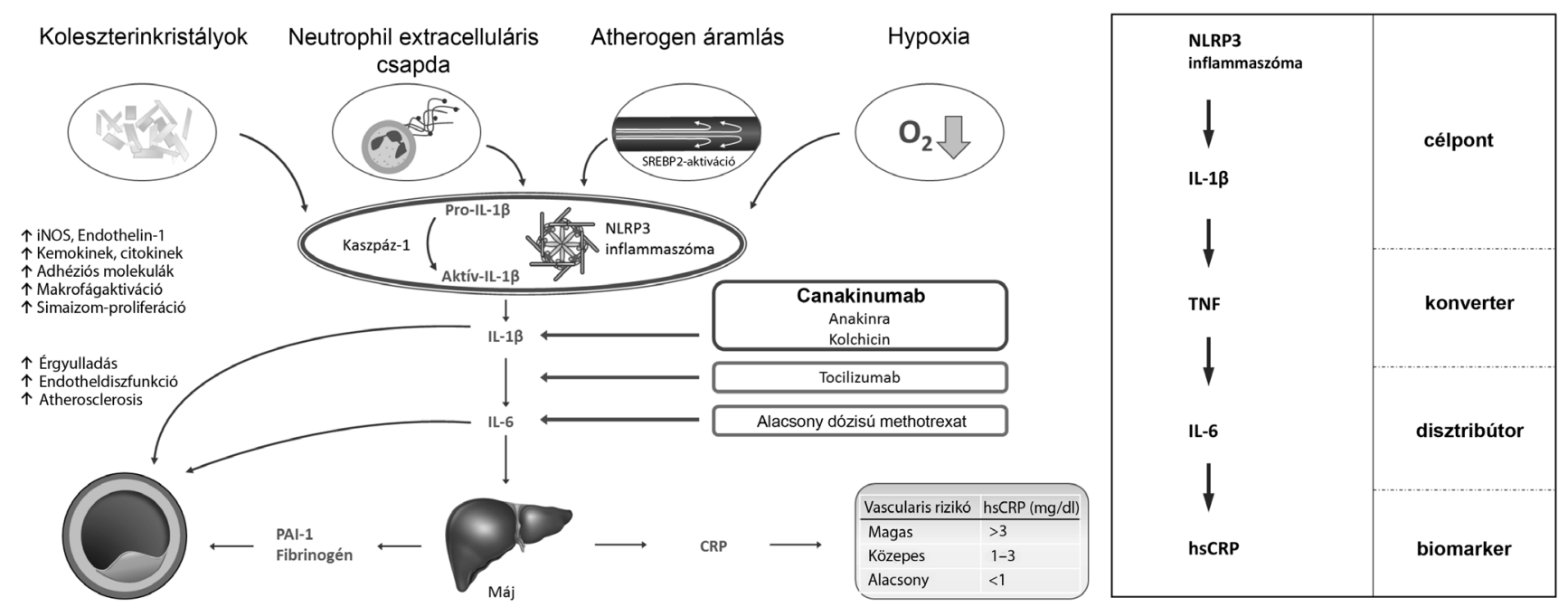

4. ábra $\quad$ A CRP-től az IL-6 és IL-1-ig - az érvédelem új célpontjai. A gyulladásgátló kezelés szerepe az érelmeszesedés kialakulásának gátlásában

$\mathrm{CRP}=\mathrm{C}$-reaktív protein; hsCRP = high-sensitivity C-reaktív protein; IL-1 = interlekukin- 1 ; IL-1 = interlekukin-1-béta; IL-6 = interleukin-6; iNOS = indukálható nitrogén-monoxid-szintetáz; NLRP3 = nucleotide-binding domain and leucine-rich repeat (NLR) family pyrin domain containing 3 ; $\mathrm{O}_{2}=$ oxigén; PAI- $\mathrm{l}$ = plazminogénaktivátorinhibitor- 1 ; TNF = tumornekrózis-faktor 
A residualislipid-kockázat csökkentésének legkézenfekvőbb, a napi gyakorlathoz legközelebb álló, klinikai vizsgálatok által a leginkább alátámasztott lehetősége az LDL-C 1,8 mmol/1 alá történő csökkentése, amihez a statinok nagy adagja mellett az ezetimib és a PCSK9gátlók adása áll rendelkezésre. Új a residualis gyulladásos kockázat csökkentésére a CANTOS-vizsgálat által igazolt lehetőség. A monoklonális antitest canakinumab 3 havonta történő adásával azt igazolta, hogy csak a gyulladásra hatva is kedvezően befolyásolható a cardiovascularis események gyakorisága. Ezek a forradalmi jelentőségü eredmények a napi gyakorlatot egyelőre nem fogják befolyásolni.

Anyagi támogatás: A közlemény megírása, illetve a kapcsolódó kutatómunka anyagi támogatásban nem részesült.

Szerzôi munkamegosztás: M. L.: A téma felvetése, a kézirat megszövegezése. H. M.: A kézirat átnézése, az ábrák szerkesztése. P. Gy.: A kézirat véleményezése. A cikk végleges változatát mindhárom szerző elolvasta és jóváhagyta.

Érdekeltségek: A szerzőknek nincsenek érdekeltségeik.

\section{Irodalom}

[1] Márk L, Harangi M, Becker D. Atherosclerosis, unstable plaque, acute coronary syndrome. [Ateroszklerózis, instabil plakk, akut koronária szindróma.] Cardiol Hung. 2015; 45: 40-47. [Hungarian]

[2] Janoudi A, Shamoun FE, Kalavakunta JK, et al. Cholesterol crystal induced arterial inflammation and destabilization of atherosclerotic plaque. Eur Heart J. 2016; 37: 1959-1967.

[3] Yusuf S, Hawken S, Ounpuu S, et al. Effect of potentially modifiable risk factors associated with myocardial infarction in 52 countries (the INTERHEART study): case-control study. Lancet 2004; 364: 937-952.

[4] Packard CJ, Weintraub WS, Laufs U. New metrics needed to visualize the long-term impact of early LDL-C lowering on the cardiovascular disease trajectory. Vascul Pharmacol. 2015; 71: 37-39.

[5] Ridker PM, Danielson E, Fonseca FA, et al. Reduction in C-reactive protein and LDL cholesterol and cardiovascular event rates after initiation of rosuvastatin: a prospective study of the JUPITER trial. Lancet 2009; 373: 1175-1182.

[6] Ridker PM. Residual inflammatory risk: addressing the obverse side of the atherosclerosis prevention coin. Eur Heart J. 2016; 37: 1720-1722.

[7] Ridker PM, Danielson E, Fonseca FA, et al. Rosuvastatin to prevent vascular events in men and women with elevated C-reactive protein. N Engl J Med. 2008; 359: 2195-2207.

[8] Cannon CP, Blazing MA, Giugliano RP, et al., for the IMPROVE-IT Investigators. Ezetimibe added to statin therapy after acute coronary syndromes. N Engl J Med. 2015; 372: $2387-$ 2397

[9] Lovadi E, Csécsei P, Lovig Cs, et al. Lipids and cerebrovascular disease - New therapeutic options in lowering LDL-cholesterol. [Lipidek és az agyérbetegség - Új lehetőségek az LDL-koleszterin-szint csökkentésére.] Orv Hetil. 2016; 157: 2059-2065. [Hungarian]
[10] Sabatine MS, Giugliano RP, Keech AC, et al., for the FOURIER Steering Committee and Investigators. Evolocumab and clinical outcomes in patients with cardiovascular disease. N Engl J Med. 2017; 376: 1713-1722.

[11] Baigent C, Blackwell L, Emberson J, et al., Cholesterol Treatment Trialists' (CTT) Collaboration. Efficacy and safety of more intensive lowering of LDL cholesterol: a meta-analysis of data from 170000 participants in 26 randomised trials. Lancet 2010; 376: 1670-1681.

[12] Ference BA, Ginsberg HN, Graham I, et al. Low-density lipoproteins cause atherosclerotic cardiovascular disease. 1. Evidence from genetic, epidemiologic, and clinical studies. A consensus statement from the European Atherosclerosis Society Consensus Panel. Eur Heart J. 2017; 38: 2459-2472.

[13] Catapano AL, Graham I, De Backer G, et al. 2016 ESC/EAS Guidelines for the Management of Dyslipidaemias. Eur Heart J. 2016; 37: 2999-3058.

[14] The recommendations of the VIth Hungarian Cardiovascular Consensus Conference. [A VI. Magyar Kardiovaszkuláris Konszenzus Konferencia ajánlásai.] Metabolizmus 2015; 13: 1-55. [Hungarian]

[15] Márk L, Reiber I. The place of fibrates in lipid lowering therapy in 2017 according to the European and Hungarian guidelines. [A fibrátok helye a dyslipidaemia kezelésében a 2017-ben érvényes magyar és európai irányelvek alapján.] Metabolizmus 2017; 15: 85-88. [Hungarian]

[16] Bowman L, Hopewell JC, Chen F, et al., The HPS3/TIMI55REVEAL Collaborative Group. Effects of anacetrapib in patients with atherosclerotic vascular disease. N Engl J Med. 2017; 377: $1217-1227$.

[17] Ference BA, Kastelein JJP, Ginsberg HN, et al. Association of genetic variants related to CETP inhibitors and statins with lipoprotein levels and cardiovascular risk. JAMA 2017; 318: 947956.

[18] Nordestgaard BG, Chapman MJ, Ray K, et al., for the European Atherosclerosis Society Consensus Panel. Lipoprotein(a) as a cardiovascular risk factor: current status. Eur Heart J. 2010; 31 : 2844-2853.

[19] O'Donoghue ML, Braunwald E, White HD, et al., for the SOLID-TIMI 52 Investigators. Effect of darapladib on major coronary events after an acute coronary syndrome: the SOLIDTIMI 52 randomized clinical trial. JAMA 2014; 312: 10061015 .

[20] Márk L, Katona A. From lipid target values to JUPITER study. Importance of the achievement of lipid levels specified by the guidelines and deficiencies in the present practice. [A lipidcélértékektőll a JUPITER vizsgálatig. Az irányelvekben elő́rt lipidszintek elérésének jelentôsége és a gyakorlat hiányosságai.] Orv Hetil. 2009; 150: 2012-2018. [Hungarian]

[21] Bohula EA, Giugliano RP, Cannon CP, et al. Achievement of dual low-density lipoprotein cholesterol and high-sensitivity Creactive protein targets more frequent with the addition of ezetimibe to simvastatin and associated with better outcomes in IMPROVE-IT. Circulation 2015; 132: 1224-1233.

[22] Ridker PM. From C-reactive protein to interleukin-6 to interleukin-1: moving upstream to identify novel targets for atheroprotection. Circ Res. 2016; 118: 145-156.

[23] Ridker PM, Everett BM, Thuren T, et al., for the CANTOS Trial Group. Antiinflammatory therapy with canakinumab for atherosclerotic disease. N Engl J Med. 2017; 377: 1119-1131.

[24] Paragh Gy, Karádi I. Up to date lipid lowering treatment. [Korszerú lipidcsökkentő kezelés.] Orv Hetil. 2016; 157: 12191223. [Hungarian]

(Márk László dr., Gyula, Semmelweis u. 1., 5700 e-mail: mark@pandy.hu) 